\title{
Storytelling in Teaching Chinese as a Second/Foreign Language
}

\author{
Kate Nguyen ${ }^{1}$, Nile Stanley ${ }^{2, *}$, Laurel Stanley ${ }^{3}$ \\ ${ }^{1}$ Shaanxi Normal University, China \\ ${ }^{2}$ University of North Florida, Jacksonville, USA \\ ${ }^{3}$ Capella University, USA \\ *Corresponding Author: nstanley@unf.edu
}

Copyright (C) 2014 Horizon Research Publishing All rights reserved.

\begin{abstract}
Storytelling has been described as the oldest technique in second language (L2) learning. Neuroscientists contend that our minds are literally wired to comprehend best the world through narrative. Researchers have claimed that the benefits of storytelling in teaching and studying second languages include increased development of language skills, improved comprehension and classroom interaction. L2 Chinese acquisition is a relatively new area of study with scant research. This survey research explored how storytelling was used in teaching Chinese as a second/foreign language (CSL/FL) in China. Participants were $15 \mathrm{CSL} / \mathrm{FL}$ instructors and 30 adult learners enrolled at the School of Chinese Language in Shaanxi Normal University, (Xi'an, China). Participants took a teacher or student survey about their interests, the practice, benefits, and challenges of doing storytelling in the CSL/FL classroom. Results of the survey indicated that the participants were interested in storytelling because of the perceived benefits of language learning, comprehension, community building, and multi-cultural understanding. This article provides guidelines and recommends resources for using storytelling as an educational strategy in the adult $\mathrm{CSL} / \mathrm{FL}$ classroom.
\end{abstract}

Keywords Storytelling, Second Language Acquisition of Chinese, L2 Teaching Strategies

\section{Introduction and Background to the Study}

The survey research explored how storytelling was used in teaching Chinese as a second/foreign language (CSL/FL) in China. Participants were $15 \mathrm{CSL} / \mathrm{FL}$ instructors and 30 adult learners enrolled at the School of Chinese Language in Shaanxi Normal University, (Xi'an, China). Stories and storytelling are widely used as a pedagogical strategy and an effective teaching method/tool (Abrahamson, 1998; Stanley \& Dillingham, 2009, 2013). Storytelling in English
Language Learning classes has been shown to enhance the four language skills of listening, speaking, writing and reading (Atta-Allan, 2012) Benefits of storytelling in teaching and studying second languages include increased development of language skills, improved comprehension and classroom interaction (Tsou \& Wenli, 2012). Learning to tell and write effective stories is an effective language learning application for students to increase their knowledge of vocabulary and grammar (Nicholas, Rossiter, \&Abbott, 2011).

Using storytelling increases learner interest; thereby, allowing learners to become engaged with the use of the target language. Personal engagement is increased from learners expressing their own stories in meaningful ways. Students and teachers often find the process enjoyable and entertaining. Storytelling provides variety in instruction activity. This old and respected teaching technique in second language (L2) acquisition helps provide a rich source of materials for language classrooms (Rinvolucri, 2008). Students develop both fluency and accuracy in L2 acquisition as a result of large amounts of comprehensible material (Krashen, 1982). According to Guariento and Morley (2001), learners' own stories are a rich source of authentic material, which provides a genuine purpose, emphasizes real-world goals, fosters classroom interaction, and promotes engagement. Sauve' (2005) suggested that educational motivation can be increased by the desire to tell stories. Shanahan (1997) claimed that the 'affective loading inherent in language can be turned to the learners' advantage' (p. 168) by building on learner successes.

The benefits of teaching through storytelling are multifaceted. Beside the language skills benefits, storytelling helps learners to develop and improve their living skills, community building, harmony atmosphere, creativity, and multi- cultural understanding among learners in classroom. Hemenover (2003) found that learners' psychological stress can be decreased and their resilient self-image also can be fostered by sharing personal stories in a safe and trusting environment in the classroom. Cortazzi and Jin (2007) tracked the progress of a group of young L2 learners who 
were using keywords and story maps to tell and retell simple stories, both in their first language (L1) and in English. They concluded that the L2 learners benefited from telling their personal stories. Scholars (Essig, 2005; Katsuhiko, 2002) have reported that the sharing of personal stories can have a positive impact on language learning.

One successful teaching method for foreign language acquisition is the Teaching Proficiency through Reading and Storytelling (TPRS) (Ray \& Seely, 1998.) TPRS originated from a kinesthetic instructional approach known as Total Physical Response (TPR) (Asher, 2000). In TPR, students physically respond by acting out newly learned L2 words and phrases. The steps and techniques in TPRS make the language spoken in class both comprehensible and engaging by careful limiting the vocabulary, constant asking of easy comprehension questions, frequent comprehension checks, and very short grammar exercises known as pop-up grammar.

Roof and Kruetter (2011) reported that studies comparing TPR and TPRS methods with traditional teaching methods indicated that students scored significantly higher on vocabulary retention tests when the TPR or TPRS methods were used. It is intuitive for experienced teachers that teaching vocabulary and grammar out of context is not the most efficient way learners acquire language; hence the consideration for enhancing pedagogy with storytelling. A sample TPRS lesson adapted from Ray and Seely (1998) and Roof and Kreutter (2011) is found in Figure 1.

There are few studies on teaching Chinese as a Second Language/Foreign Language or the approaches, challenges and how storytelling is used. In this study, survey research is used to examine learners and instructors' interest in storytelling in a Chinese as a Second Language classroom in China, how storytelling used in CSL/FL, and participants feelings and wishes about storytelling in class.

\section{Method}

This survey research study investigated the perceptions about storytelling of teachers and students in the CSL/FL college classroom in China. The research questions in this study addressed the following issues:

Research Question 1: Does storytelling have wide acceptance by instructors and learners in Chinese as Second Language classrooms?

Research Question 2: What are types of stories do instructors and learners often use in Chinese as a Second Language classes?

Research Question 3: What are the educational benefits of storytelling in Chinese as a Second Language classroom?

\section{Participants}

Participants were 30 adult learners (18-35 years old) studying Chinese and 15 instructors (24-36 years old) teaching Chinese at the School of Chinese Language, Shaanxi Normal University (Xi'an, China). The learners came from different countries and spoke different languages as their primary language. They came to China to study Chinese as a Second Language.

The duration of the Chinese L2 class was 14 weeks, meeting Monday through Friday, 8 am till $12 \mathrm{pm}$. The language curriculum would be considered traditional and typical of what students encounter in most foreign universities. The emphasis was on developing reading, writing, speaking, and listening skills with focused instruction on phonetics, vocabulary, phrases, grammar, and calligraphy.

The majority of the 30 adult students in the study were overseas students who studied Mandarin Chinese as a second language for the purpose of preparing for higher education at the university. Most students were committed to a long term study of Chinese for 12 or more months while they were concurrently enrolled in a master's or doctoral program in education or psychology. Some non-degree seeking students enrolled in the class for one semester or less for an introduction to Chinese language and culture.

Fifteen different teachers assisted in teaching the class and focused on their expertise in Chinese character writing, reading, or speaking. The primary teaching method was intensive lecturing complimented with discussion and students completing grammar exercises with instructors providing feedback. On occasion, some instructors would use a storytelling activity to support language learning with the Teaching Proficiency through Reading and Storytelling (TPRS) (Asher, 2000; Ray \& Seely, 2004).

\section{Sample of Vocabulary Lesson with Storytelling}

A typical vocabulary development lesson with storytelling would consist of the teacher writing four related phrases on the board, and then students would read, pronounce and discuss the words in small groups. Next each student would write a story using each phrase in context, then read aloud and/or tell his/her story to the class. The instructor would provide comment on each story, analyzing whether the words were pronounced correctly with the appropriate meaning for the context. Follow-up applications included speaking .reading, writing and grammar activities. In Figure 1 is a sample TPRS lesson.

\section{他（姑）唱歌唱得很大声- he/she sings loudly \\ 他（妮）跳舞 -he/she dances \\ 他（她）生气 - he/she is angry \\ 他（娕）笑- they laugh}

Figure 1. A Sample basic TPRS Lesson: (format was adapted from Ray \& Seely (1998) and Roof \& Kreutter (2011).

Step 1 - Gesture - The phrases above are written on the board in English and Mandarin Chinese. Students invent a 
gesture to coincide with each word or phrase (e.g., for," 他 （她）跳舞”students mime dancing.) The students mime the actions when the teacher says the words in Chinese. This is practiced until the students can mime the actions easily without referring to what the words mean in English.

Step 2 - Personalized Questions and Answers - Students are asked questions based on the above words to begin to personalize the vocabulary. The questions are asked in Chinese: Who sings? Do you sing loudly or softly? Who sings like Hannah Montana? Who sings like Elvis? Do you sing romantically? What do you sing? Do you sing at home, in the car, or at school? Where do you sing?

Step 3 - Story - Using the answers to the question from the previous step, the teacher creates a personalized story about the students in the classroom. The following is a framework for a basic short story.

弗雷德是学生。弗雷德在上数学课时唱歌唱得很大声。 他在桌子上唱歌, 跳舞。老师很生气。学生们都笑了。

Translation: Fred is a student. Fred sings loudly in math class. He sings and dances on the desk. The teacher is angry. The students laugh.

Step 4 - Dramatize - Using students as actors, the instructor retells the story and has the students act it out.

Step 5 - Apply - Students practice using the Chinese phrases in conversation, through reading, grammar and writing exercises.

\section{Data Collection Surveys}

There were two surveys in the study used for data collection: one survey for teachers and the other survey for students. The surveys were organized into three groups of questions according to the three research questions. See the results section for survey questions and responses.

\section{Survey Results}

\section{Teacher Survey, $\mathbf{N}=15$ teachers}

Research Question 1: Does storytelling have wide acceptance by instructors and learners in Chinese as Second Language classrooms?

Table 3. Teacher goals of storytelling

\begin{tabular}{|c|c|c|c|c|c|c|c|c|}
\hline & \multicolumn{8}{|c|}{ Highest $(1,2,3 \ldots$ to least priority 8} \\
\hline & $1^{\mathrm{st}}$ & $2^{\text {nd }}$ & $3^{\text {rd }}$ & $4^{\text {th }}$ & $5^{\text {th }}$ & $6^{\text {th }}$ & $7^{\text {th }}$ & $8^{\text {th }}$ \\
\hline Vocabulary & 15 & 0 & 0 & 0 & 0 & 0 & 0 & 0 \\
\hline Idioms and Figurative Language & & & & 9 & 2 & 3 & & \\
\hline Cultural Awareness & & 4 & 6 & & & 2 & 4 & \\
\hline Grammar & & 9 & 4 & 5 & & & & \\
\hline Suprasegmentals & & & 2 & & 3 & 7 & 2 & 2 \\
\hline Rate of Speech & & & & & & & & \\
\hline Segmentals (consonants and vowels & & & 4 & & 2 & 6 & 2 & 2 \\
\hline Other: & & & & 2 & & & 7 & 9 \\
\hline
\end{tabular}

1.1. What class are you teaching: beginners, intermediate or advanced? 5 teachers had beginner classes, 6 teachers had intermediate classes, and 4 students had advanced classes.

1.2. Do you use storytelling in the classroom? All 15 instructors used storytelling

1.3. If you use storytelling, does the teacher or the students do most? All teachers reported that teachers and students did storytelling evenly.

1.4. Do you think students like storytelling in the classroom? All instructors reported that their students liked storytelling, either very much or liked.

Table 1. Instructors reported students liked storytelling.

\begin{tabular}{|c|c|c|c|c|}
\hline & Very much & Like & $\begin{array}{c}\text { Not very } \\
\text { much }\end{array}$ & $\begin{array}{c}\text { Do not } \\
\text { like }\end{array}$ \\
\hline $\begin{array}{c}\text { Teacher } \\
\text { Answers }\end{array}$ & 7 & 8 & 0 & 0 \\
\hline
\end{tabular}

$\mathrm{N}=15$

1.5. Do students like telling stories or listening to stories?7 of 15 teachers reported that their students preferred listening to telling stories and 6 of them said their students like telling and listening stories about evenly, 2 of them said the students preferred telling stories to listening, and no teachers said it depended.

Table 2. Instructors report student preference for listening or telling stories.

\begin{tabular}{|c|c|c|c|c|}
\hline & $\begin{array}{c}\text { Prefer } \\
\text { listening to } \\
\text { telling } \\
\text { stories }\end{array}$ & $\begin{array}{c}\text { Prefer } \\
\text { telling } \\
\text { stories to } \\
\text { listening }\end{array}$ & $\begin{array}{c}\text { About } \\
\text { evenly }\end{array}$ & It depends \\
\hline $\begin{array}{c}\text { Teacher } \\
\text { Answers }\end{array}$ & 7 & 2 & 6 & 0 \\
\hline
\end{tabular}

$\mathrm{N}=15$

1.6. What are the goals of storytelling? Please list your goals in order of importance? Highest $(1,2,3$...to least priority 8). Vocabulary was the most important goal for teachers. 
1.7. I would use storytelling more but...

The following were responses from instructors.

- Stories probably affect the content of the lessons as well the school's demand in content of the course.

- Need to follow the schedule for the lessons in class; stories need to be used in simple way for students to understand.

- Need to find suitable chance and right time, such as try to use new vocabulary in stories.

- There some stories too difficult for students to understand (because of their limited vocabulary and words) while there some too simple for them. Moreover, sometimes storytelling takes time in class.

- Time for class is not very often enough for doing extra activities, means there many other important things to do.

- Sometimes find hard to get suitable stories for students' level.

\section{Section 2, Research Question 2}

2.1. What types of stories you often use in the classroom? More than one response may be selected. 10 instructors reported that they often used personal stories; some instructors said they sometimes used folktales and literary stories

Table 4. Types of stories that instructors use in the classroom.

\begin{tabular}{|c|c|c|c|c|}
\hline & $\begin{array}{c}\text { Folktales (Children's } \\
\text { stories about animals, } \\
\text { kings, queens, magic, } \\
\text { etc.) }\end{array}$ & $\begin{array}{c}\text { Literary stories } \\
\text { (Stories retold from } \\
\text { books or movies) }\end{array}$ & $\begin{array}{c}\text { Personal stories (True } \\
\text { stories about your life, } \\
\text { family or friends) }\end{array}$ & $\begin{array}{c}\text { Blended stories } \\
\text { (Stories that blend the } \\
\text { personal + Folktale or } \\
\text { + Literary) }\end{array}$ \\
\hline Teacher Answers & 4 & 5 & 10 & 4 \\
\hline
\end{tabular}

$\mathrm{N}=15$

2.2. Where do you obtain your resources and materials for telling stories? More than one may be selected.

Most teachers claimed that their resources and materials for storytelling were from books and internet. Some used personal stories about their own experiences or people around them to express new grammar structures or vocabularies for learners to understand in class.

Table 5. Source of stories for instructors were most the Internet and books.

\begin{tabular}{|l|c|c|c|c|c|}
\hline & Internet & Books & Magazines & Comics & Other \\
\hline Teacher Answers & 13 & 15 & 7 & 3 & 3 \\
\hline
\end{tabular}

$\mathrm{N}=15$

\section{Group 3, Research Question 3}

What are the benefits of using storytelling in the classroom? Language Skills, Social/Communication Skills, Speaking Skills, Reading Comprehension were stated to be benefits.

Table 6. Instructors perceived benefits of storytelling.

\begin{tabular}{|c|c|c|c|c|}
\hline & Language skills & Communication skills & Speaking skills & Reading Comprehension \\
\hline Answers & 15 & 15 & 12 & 11 \\
\hline
\end{tabular}

$$
\mathrm{N}=15
$$

3.1 With which language proficiency level do you use stories? Students used a mix of proficiency levels: Beginners $=4$, Intermediate $=7$ or Advanced $=4$.

\subsection{Do you think students often show their personalities while they do storytelling? Results showed that students most often showed their personalities in storytelling.}

Table 7. Personalities of students were shown in storytelling

\begin{tabular}{|c|c|c|c|c|}
\hline & Often & Sometimes & It depends & Never \\
\hline Answers & 9 & 4 & 2 & 0 \\
\hline
\end{tabular}

$\mathrm{N}=15$

3.3 What are the reasons you want to listen to your students' stories? Most common reasons were teachers wanted to listen 
to student communication skills, character skills, and interest in the language.

Table 8. Frequencies of reasons instructors wanted to listen to students' stories.

\begin{tabular}{|c|c|c|c|c|c|c|c|}
\hline & A & B & C & D & E & F & G \\
\hline TeacherAnswers & 6 & 4 & 3 & 7 & 2 & 7 & 8 \\
\hline
\end{tabular}

$\mathrm{N}=15$

Key, A. Interest in study language, B. Attitude of study, C. Consciousness of study, D. Characters, E. Intelligence , F. Abilities , and G. Communication skills

3.4 Does storytelling in class help students in which of the following? Ranking the most common reason was to improve language skills, and the second most common reason was to make the lessons enjoyable.

Table 9. Ranking of how storytelling helps students.

\begin{tabular}{|c|c|c|c|c|c|c|}
\hline & \multicolumn{6}{|c|}{ Quantify of evaluating } \\
\hline & $\begin{array}{c}\text { The most } \\
\text { important }\left(1^{\text {st }}\right)\end{array}$ & $2 \mathrm{st}$ & 3 nd & 4 th & 5 th & 6th \\
\hline Language skills & 11 & 0 & 6 & 0 & 0 & 0 \\
\hline Enjoy class & 3 & 3 & 5 & 0 & 4 & 0 \\
\hline $\begin{array}{c}\text { Understandeach } \\
\text { other }\end{array}$ & 0 & 0 & 8 & 5 & 2 & \\
\hline $\begin{array}{l}\text { Learn about } \\
\text { other cultures }\end{array}$ & 0 & 0 & 0 & 7 & 7 & 0 \\
\hline $\begin{array}{c}\text { Learn about the } \\
\text { culture } \\
\text { (Chinese } \\
\text { culture) } \\
\end{array}$ & & 8 & 4 & 1 & 0 & 0 \\
\hline Others & 0 & 0 & 0 & 0 & 0 & 15 \\
\hline
\end{tabular}

$\mathrm{N}=15$

\subsection{Complete following sentences}

Using storytelling makes me feel....

- Relaxed, imagery, understand or approach students' lives, practical

- Make lessons realistic and more useful

- Excited in teaching because storytelling makes students want to be or to be parts in stories so that they more interested in study.

- Learn more about different culture as well people's lives among students while they share their stories.

- Can understand students with their emotions, feelings, demands and how well how they understand lessons.

- Find out students' wishes, methods in studying and learn if they do well or not in their study language

- Easier for me to introduce/explain vocabulary as well grammar to students

Using storytelling makes our students....

- Have more chances to communicate as well understand among them the students

- Practice vocabulary in many different situations.

- Learn how to use vocabulary and grammar correctly

- Improve their skills very well

- Show their feelings, emotions... as well their methods in studying and the way of thinking in life.

- Encourage their creativity in finding ways to study as well understand lesson.
- Get involved with other members (classmates) in class.

- Encourage them to take part in class's activities.

- Feel more relaxed and interested in study.

\section{Student Survey, N-30}

Research Question 1: Does storytelling have wide acceptance by instructors and learners in Chinese as Second Language classrooms?

1.1 Do you enjoy storytelling in the classroom? 24 students

liked storytelling, 6 students liked it very much.

1.2 If you enjoy storytelling, please list the reasons in order of importance? According to the learners the most important reasons they enjoy storytelling in class were as follows (highest to least priority):

1. Help them to improve their language

2. Make them enjoy studying in class;

3. Make the classmates understand each other better;

4. Learn more about the other cultures of our fellow students

5. Learn more about the other cultures of the language they are studying (Chinese culture).

1.3. Do your teachers use storytelling in the classroom? 11 students reported that teachers used storytelling frequently. 15 reported that storytelling was used occasionally, and 4 students said that storytelling was at least used once per semester. No student reported that storytelling was never used. 
1.4. Do you or the teachers do most of the storytelling? Students reported that they and their instructors did storytelling about evenly. 8 of 30 students said most of the time the people who did storytelling were the teachers. Only 4 of them said the students did most of the storytelling. 1.5. Do you prefer that the students or the teachers to do most of the storytelling? In classroom, most of the learners claimed that they preferred that the learners and their instructors did storytelling evenly (18 students). 12 students reported that it depends on the lesson as to who does the storytelling.

1.6.Do you like telling or listening to storytelling in classroom? Most learners (11 students) said they like telling and listening about evenly, 8 students of 30 learners reported that it depended on situations and the lessons in classroom whether they found it necessary to tell or listen more often in class.

1.7. Do you prefer that the teachers tell stories, read stories, some of each, or whatever? Students (7) answered that they like teachers telling stories or (19) evenly telling or reading. 4 students preferred teachers to read stories.

\section{Section 2, Research Question 2}

2.1. What types of stories do you often tell in the classroom: (Can choose more than one, or all) (a) Folktales, (b) Literary stories, (c) Personal stories, or (d) Blended stories. 20 learners reported that they often used personal stories. 5 said they used folktales. 2 learners said they use literary stories. 3 students used blended stories.

2.2. What types of stories do teachers often tell you? 13 students responded that personal stories were most common. 8 students responded that folktales were most common. 4 reported literary stories and 5 reported blended stories.

\section{Group 3, Research Question 3}

3.1. What benefits do you think storytelling has in the classroom? Students listed the following in order of importance.

1. Culture Awareness,
2. Vocabulary
3. Idioms and Figurative Language
4. Segmentals (consonants and
vowels)
5. Suprasegmentals (stress and
intonation)
6. Grammar
7. Rate of speech

3.2. Do you think the storyteller often show their own emotions, attitudes, viewpoints of life... when they tell stories in class? 7 students confirmed that this always happened, 13 students said it sometimes did, 10 students said it depended, and no students said storytelling had no effect their emotions, attitudes.

3.3 Please complete each of the following sentences.

Storytelling makes me feel... because....

In general, mostly students reported that storytelling in class made them enjoy the lesson, feel entertained, happy, excited lessons and reduce stress, and it made lessons more interesting. In doing stories other people could contribute and everyone could introduce different, interesting parts of their lives. They claimed that storytelling helped as a means to connect cultural experiences because doing stories they could learn more and have awareness of Chinese cultural in which the language they studying, as well understanding about Chinese people' belief and the custom of the people. Moreover, they could learn much about other cultures and the people, the new things that a world outside their own and often they could relate with the story teller because of the diversified stories they shared in class. They could learn about more each other and make good relationships. It increased solidarity among their students, and it made their teachers' lecture more interesting with varieties stories as good examples that they could learn from; learn not only about the writer's or teller's ways to tell their stories but about their emotion, opinions, feelings. They found their creativity and imagination would be improved a lot while they were doing or creating stories. The students added that storytelling helped them to tell of their similarities and differences, their strengths and weaknesses, as well as their hopes and dreams. The reasons they gave for these are because the experience of their classmates was shared while they doing story; storytelling created a good atmosphere and how to express personal experiences that made they engaged with their fellow classmates and teachers on a personal level

Doing storytelling has helped me with....

Students all admitted that storytelling helped them a lot with their language skills. It helped them easily fall in line with their peers. They could also learn a lot from doing storytelling. Here is a sample from a learner: "My language skills improved, like enriched vocabularies. I can get familiar with Chinese culture and put together my thoughts in Chinese language, by doing storytelling in class. My confidence and innovation enhanced when talking to people about my own stories".

\section{Analysis of Survey Data}

\section{Research Question 1: Acceptance of Storytelling by Instructors and Learners in the Chinese Language Classroom:}

All instructors and learners who completed the survey indicated that they enjoyed storytelling and six students liked storytelling very much. Instructors responded that they liked storytelling in the classroom and all the 15 instructors said they used storytelling very often in their classes. 11 learners indicated that their instructors use storytelling frequently. 15 learners said storytelling was used occasionally. 4 learners said instructors use storytelling at least once during the semester, and no learners reported never using storytelling. There were similar responses between the learners and the instructors.

The learners ranked the most important reasons they enjoyed storytelling in class from the highest to least priority in this way: 1) Improves language learning; 2) Helps to enjoy studying in class; 3) Helps classmates understand each other better; 4) Improves learning about the other cultures of our 
fellow students; and 5) Increases learning about the Chinese culture.

Most learners claimed that the learners and their instructors told stories evenly and teachers responded similarly to the same question. When learners were asked: "Do you like telling or listening stories in classroom", most learners said they liked telling and listening about evenly, some learners reported that it depended on situations and the lessons in classroom. 7 of 15 instructors reported that their students preferred listening to telling stories and 8 of them said their students like telling and listening stories about evenly. Two instructors said the students preferred telling stories to listening.

Most the learners answered they liked listening to teachers. Some learners (12) reported they preferred listening to teachers and classmates about evenly, and only 3 learners said that they liked to listen to classmates do storytelling. They also reported that they and their instructors used storytelling about evenly. 8 of 30 students said most the time, teachers did storytelling and only 4 of them said students do most storytelling.

When learners were asked "Which do you like the teachers to do: telling stories, reading stories, or about evenly?" Most of the learners answered that they liked teachers telling stories (13), or evenly telling and reading. This answer was confirmed in the teachers' report, they all (15 instructors in the survey) supposed that their students liked teacher to tell stories.

From this data of the survey, we find that storytelling was accepted for use by teachers and students in L2 Chinese classes. The instructors used storytelling as a teaching method, to explain the meaning of vocabularies and to make their lessons more interesting.

Research Question 2: What are types of stories do instructors and learners often use in Chinese as a Second Language classes?

To learn about what types of stories are often used in class, the teachers were asked: "Where do you obtain your resources and materials for telling stories?" Most of them claimed that their resources and materials for storytelling are from books and the internet. Some of them often use personal stories about their own experiences or people around them to express new grammar structures or vocabularies for learners to understand in class.

To learn about what types of stories were often used in class, most instructors and learners reported that they often used personal stories (10 instructors and 13 learners). Some instructors used folktales and literary stories, and most learners said they rarely use literary stories. Personal stories typically focus on a family member overcoming challenge .An example of the start of a personal story is "let me tell you about how my uncle from Vietnam who came to China many years ago to start a restaurant business. Learning to speak Chinese quickly and fluently made him popular and his business soared."

Research Question 3: What are the educational benefits of storytelling in Chinese as a Second Language

\section{classroom?}

The instructors reported that the goals in order of importance of using storytelling (from highest to least priority ) were 1) Vocabulary, 2) Cultural Awareness, 3) Idioms and Figurative Language, 4) Grammar, 5) Suprasegmentals (stress and intonation), 6) Rate of Speech, 7) Segmentals (consonants and vowels), and8) Confidence, Fluency, Thought groups, Critical thinking, Organization of ideas, Humor and community building, Listening skills, Social skills. They said that storytelling created chances for the learners to use vocabularies and grammar correctly. The specific contexts in stories helps learners concentrate, which encourages them to participate, improve their skills, become involved with other members (classmates) in class, feel more relaxed and interested in study; reduce stress or pressure from the mission of lessons; and create easier to understand lesson.

Most learners in the survey supposed that storytelling could enhance 1) Culture Awareness, 2) Vocabulary, Idioms and Figurative Language, 3) Segmentals (consonants and vowels); 4) Suprasegmentals (stress and intonation); 5) Grammar; 6) Rate of Speech, 7) Other benefits like confidence, fluency, study groups, critical thinking, organization of ideas, humor and community building, listening skills, and social skills.

Learners said that storytelling helped them with their language skills. One learner said "My language skills improved, with enriched vocabularies. I can get familiar with Chinese culture, and put together my thoughts in the Chinese language, by using storytelling in class. Also, my confidence and innovation were enhanced when talking to people about my own stories."

For this data, we find there was no difference of the lingual benefits of doing storytelling in class between the instructors and learners. The instructors and learners in the interviews all reported that doing storytelling helped the learners' language skills develop. Learners listened, shared stories and became more intimate with their language by developing, expanding, and increasing language skills while interacting and communicating.

To learn about the storytelling benefits to psychology of the learners in CSL/FL the learners were asked: "Do you think the storyteller often show their own emotions, attitudes, viewpoints of life... when they tell stories in class?" 7 learners confirmed that it always happened, 13 learners said it sometimes did, 10 learners said it depended, and no learners said storytelling had no effect their emotions, attitudes. 9 of 15 the instructors reported that students often showed their personalities while they did storytelling, 4 of them said this sometimes happened, while no the teachers said it never happened. This showed that more natural and complete language input was may have helped students show their personalities.

The participants were asked to complete the following sentence: Storytelling makes me feel... because.... These following are some of the students' responses: "I can learn about different people's experiences or opinions"; 
"Storytelling made me feel very interesting, feel like I am a part of the eye"; "made me to be engaged in the stories...." They claimed that storytelling helped as a means to connect cultural experiences because they could learn more and have awareness of Chinese culture in which the language they are studying, as well understanding about Chinese people' beliefs and the customs of the people. They could learn much about the cultures of the other people in the class.

For the instructors, they were asked: "What are the reasons you want to listen to your students' stories?" they often chose the following reasons: "Because I can learn about their communication skills, attitudes, characters and their interest in study language" Some of them said they could learn the students' approach to language study, or about the students' intelligence.

When instructors were asked to complete the sentence, "I would use storytelling more but..." the instructors reported these reasons. First, they felt students' personal stories might distract the class from focusing on academic content. Additionally, instructors needed to follow the schedule of the lessons in class. Storytelling takes extra time in class. Stories needed to be used in a simple way for students to understand. Using stories required the suitable chance and right time.

There were some stories too difficult for students to understand (because of their limited vocabularies), while some were too simple. Students have limited vocabularies when in the beginning level so that it is hard to find the right stories for students' levels in class.

The following is a sample from one of the instructors' responses, who wrote "I would use storytelling more but our school's plan is a tough offering. We need to follow the schedule of lessons in class. Stories need to be used in simple way for students to understand. Using new vocabulary in stories needs to be used at the right time in lessons... all these issues take time while there are lots of missions in class we have to follow."

\section{Discussion}

Storytelling was accepted to use widely in classrooms as L2 Chinese Language in Shaanxi Normal University. Both the instructors and learners were interested in doing storytelling in classroom. They found storytelling was an effective mean and a good teaching tool. However, using storytelling in the classroom still is done separately in simple ways without specific strategy and the aids of psychological orientations. From this, further research is needed to focus on finding psychological aspects of tellers and listeners during doing storytelling process. Then, research is needed to find principles/guidelines to consult instructors how to do storytelling and to organize for their learners how to do storytelling in language class effectively.

There was no wide difference of opinions about the benefits of doing storytelling in class among instructors and learners. Most of them agreed storytelling leads to improve language skills as students engage in storytelling and story enactments themselves. By using stories students could begin to recognize and to understand how stories are structured - necessary knowledge and skills for both reading and writing. If new ideas and concepts are taught within the context of a story, the chance of the student understanding the material will likely be improved since the student can experience an array of familiar details while also being introduced to new concepts. A story can thus promote learner interaction and reaction to the concepts being taught. Accessing the internal state allows the learner to more readily interact with the new (external) material being presented. We thus find storytelling have a power to make students improve not only their language skills, reduce stress for them while studying in class, but also to be a means to form and improved students' characteristics and brings emotional benefits. These benefits are improved emotional intelligence, creativity, tolerance, and learning how to live in harmony.

There are various types of stories using in the study of L2 Chinese language. However, the teachers and students in the survey tended to use personal stories very often in class and blended stories. Further studies are needed on finding a guide for instructors and learners on how to use personal stories, as well to integrate different types of stories in class. Creating appropriate personal stories from ones' own experiences is one of the rich and interesting material sources for teaching and studying Chinese language as L2.

Learners tend to prefer listening to teachers telling to reading stories because they can touch the feelings and emotions of tellers shown during doing storytelling. This leads to learning from others' experiences in life and learning about lessons how to form their ways of living in complicated society. Thus, psychology research might focus on orientations of adjusting psychology of tellers (teachers and students) such as how to control tellers' emotions while doing storytelling, or how to spread/impact good influence to students beyond goals of improving language/literature skills.

Interestingly, while studying Chinese language, learners not only study it as L2 but also to find it interesting to learn about the meaning of the way how to write Chinese characters. We can say that Chinese character is a beautiful mean of transit religion, values, history, traditions, and customs of the country which they study the language. For this, further research need to deal about finding the benefits of Chinese character on teaching this language as L2 for learners. This can give suggestions/ guidelines for instructors how to create and encourage learners create stories based on Chinese Characters.

Teachers of CSL/FL often lack basic resources, materials, credentials, and access to research and its application of language acquisition (Linnell, 2001). Furthermore, the traditional Chinese teacher centered, traditional curriculum can hinder opportunities for student engagement through storytelling (Stanley\& Meng, 2012). There are few opportunities to learn from professional storytellers who use total physical response masterfully to bring adult language 
alive with voice, movement and expression drawing from a rich palette of story types including folktales, personal, literary and blended. The effective use of combining storytelling, story reading and story writing for effective language instruction is unclear.

Classroom contexts for CSL/FL have changed from a grammar translation approach for the purpose of predominantly training foreigners to read and understand academic Chinese texts and lectures to a diversity of classrooms in terms of their objectives, teaching methods, and student profiles (Linnell, 2001). Students are motivated to study Chinese for a variety of purposes, including personal, pleasure, and daily life, occupational, cultural and academic. Respecting learners and their right to nonparticipation is suggested for teachers. Students may prefer to write or digitize a story instead of telling it, develop a sense of community in the class, and value the wealth of learners' personal stories and experiences (Nicholas, Rossiter, \&Abbott, 2011.) Understanding the value of storytelling and making time for it can address student diversity within the classroom. Matching storytelling types with student objectives is recommended for effective teaching practice. For example, a prospective primary teacher might thrive on telling Chinese folktales that he/ she can use in teaching children. A graduate student in psychology interested in counseling might enjoy hearing and telling personal stories of resilience.

\section{Developing a Repertoire of Storytelling Strategies}

The TPRS (Teaching Proficiency through Reading And Storytelling) is a widely used method (Ray \&. Seely, 1998) and instructors are encouraged to study it, attend workshops or learn it from an experienced peer instructor. Language programs tend to emphasize the content of grammar and vocabulary over the processes and dispositions needed to motivate and engage learners. For students to learn how to perform stories well the teacher must be a model. Inviting a professional storyteller to the language class is essential because our experience in China revealed that classes tend to be lecture based with few opportunities for truly dramatic storytelling. Teachers may need patience and building of trust to move quiet, reserved students from passive listeners to actively perform their stories with voice, movement and expression. As with all new skills, start by teaching the basics and gradually work up to more sophisticated techniques (Stanley \& Dillingham, 2009).

\section{Use Social Networking Sites to Promote Storytelling outside of Class}

Teachers can integrate social learning websites into both languages learning and teaching. Meng and Stanley (2012) reported on a student-initiated English as a Second Language learning community based on Renren (the Chinese version of Facebook). Findings suggested social identity, perceived encouragement, and perceived ease of use are factors that affect the interaction of social networking-based learning community in a positive way. Social networking sites support collaborative learning, engage individuals in critical thinking, and enhance communication and writing skills through activating members' work in personalized environments. Importantly, multimedia learning resources and materials found online can accommodate different learning preferences and needs. With the ability to post videos, photos, and other resources, students can share content easily with others, and give feedback about resources and materials. For example, teachers could upload teaching materials (different story types to read, vocabulary, with accompanying picture and videos to stimulate storytelling) before class for students to preview. Students are also able to share ideas on materials which may help to promote communication.

Stanley and Dillingham (2011) developed and researched a digital storytelling development strategy model for second language learning. Digital storytelling is storytelling that contains some mixture of computer-based images, text, recorded audio narration, video clips, or music. They developed digital storytelling activities for second language learning for beginning, intermediate, and advanced level students, based on their technological skill and language proficiency. For example, a CCL/FL might introduce a digital recipe book with interesting stories compiled by the class. The learner's storytelling is more important than the technology. Technology can enhance a story. An engaging story with an interesting beginning, problem, solution, and ending should be the driving force behind any project.

\section{Conclusion}

Storytelling is practiced in Chinese Language Learning as a Second Language at Shaanxi Normal University. Both instructors and learners reported using storytelling in the classroom, but the researchers' concluded storytelling is not used as it could be and its full potential has not been realized. Participants in the study found storytelling an effective strategy for language learning and a good teaching tool. However, using storytelling in the classroom in China is still viewed as something separate, less esteemed as academic content, despite its many benefits. The authors agree with Zhao (2011) that future research on teaching with storytelling should include larger sample sizes, more longitudinal studies and investigation of how different L1 languages affect $\mathrm{L} 2$ learning.

The psychological benefits of teaching with storytelling are still not clearly understood. Further research is needed to focus on finding psychological aspects of tellers and listeners during the storytelling process. Also research needs to illuminate the principles/guidelines that would better inform instructors how to use storytelling for teaching and therapeutic psychological benefit. The full impact of digital storytelling on language learning has yet to be thoroughly researched. There is much needed research on digital learning with a particular focus on the identification of evidence and increasing the level of understanding of what 
strategies and innovations work for what students under what circumstances.

In this survey research, there was no wide difference of opinions about the benefits of storytelling in class among instructors and learners. Most agreed storytelling leads to improved language skills as learners engage in storytelling and story enactments. By using stories, learners could recognize the structure of language. New concepts and ideas are taught within the context of the story, and the chance for students to understand the material is improved. A story can promote learner interaction and reaction to the concepts being taught. The researchers conclude that storytelling is an approach that students and teachers perceive as beneficial. The full potential of storytelling has not yet been reached. This potential should be explored and promoted in CSL/FL and similar context.

\section{REFERENCES}

[1] Abrahamson, C.E. (1998). Storytelling as a pedagogical tool in higher education, Education, 118(3), 440-451.

[2] Asher, J. (2000). Learning another language through actions (7th ed.). Sky Oaks, CA: Sky Oaks Productions.

[3] Atta-Alla, M. N. (2012). Integrating language skills through storytelling. English Language Teaching, 5, 12.ISSN 1916-4742 E-ISSN 1916-4750

[4] Cortazzi, M., \& Jin, L. (1996).Cultures of learning: Language classrooms in China, In H.Coleman (Ed,), Society and the language classroom (pp, 169-206). Cambridge, MA: Cambridge University Press.KOTESOL Conference. Retrieved from: http://www.kotesol.org

[5] Cortazzi and Jin (2007) Cortazzi, M., \& Jin, L. (2007). Narrative learning, EAL and metacognitive development. Early Child Development and Care, 177, 645660. doi:10.1080/03004430701379074

[6] Essig, W. (2005). Storytelling: Effects of planning, repetition and context. In C. Edwards \& J. Willis (Eds.), Teachers exploring tasks in English language teaching (pp. 201 -213). Houndmills, London: Palgrave Macmillan.

[7] Gilmore, A. (2007). Authentic materials and authenticity in foreign language learning. Language Teaching, 40, $97-118$. doi:10.1017/S0261444807004144

[8] Guariento, W., \& Morley, J. (2001). Text and task authenticity in the EFL classroom. English Language Teaching Journal, 55, 347 -353. doi:10.1093/elt/55.4.347

[9] Hemenover, S.H. (2003). The good, the bad, and the healthy: Impacts of emotional disclosure of trauma on resilient self-concept and psychological distress. Personality and Social Psychology Bulletin,

[10] Katsuhiko, S. (2002, February). One Japanese SHS teacher's story of storytelling. The Language Teacher, 26(2), np.

[11] Krashen, S. (1982). Principles and practice in second language acquisition. New York: Prentice-Hall.

[12] Linnell, J.D. (2001). Chinese as a second/foreign language teaching and research: changing contexts and teacher choices. Language Teaching Research. 5(1),54-81.

[13] Meng, Y, \& Stanley, N. (2012, August). Social climbing: The educational value in social networking sites. Language Magazine. Retrieved on May 21, 2013 from $\mathrm{http}: / /$ languagemagazine.com/?p=4592

[14] Nicholas, B. J., Rossiter, M. J., \& Abbott, M. L. (2011).The power of story in the ESL classroom. Canadian Modern Language Review, 67(2), 247-268.

[15] Ray, B.; Seely, C. (1998). Fluency Through TPR Storytelling: Achieving Real Language Acquisition in School (2nd ed.). Command Performance Language Institute, Blaine Ray Workshops.

[16] Rinvolucri, M. (2008).EFL's oldest technique: Storytelling. Proceedings of the 2008 Seoul, KOTESOL Conference. Retrieved from: http://www.kotesol.org.

[17] Roof, L. M., \& Kreutter, C. A. (2010). An interactive storytelling puzzle: Building a positive environment in a second language classroom. Networks: An Online Journal For Teacher Research, 12(1), 1-10

[18] Suave', V. (2005). Storyweavers: Holistic education for ESL/EFL learners. TESL Canada Journal/Revue TESL $d u$ Canada, 20(1), 89102.

[19] Shananhan, D. (1997). Articulating the relationship between language, literature and culture: Toward a new agenda for foreign language teaching and research. The Modern Language Journal, 81, 164-174. doi:10.2307/328784.

[20] Stanley, N. \& Meng, Y. (2012, March). Recognizing the learner: The effect of culture on the learning process. Language Magazine, 10 (6) 24-29.

[21] Stanley, N. \& Dillingham, B. (2011, February). Making learners click with digital storytelling. Language Magazine, 10 (6) 24-29.

[22] Stanley, N., \& Dillingham, B. (2009). Performance literacy through storytelling. Gainesville, FL: Maupin House.

[23] Thou, W., \& Wenli, T. (2012). The effects of storytelling on adult English learning. English Teaching and Learning, 36, 2, $1-34$.

[24] Zhao, Y. (2011). Review article::A tree in the wood: A review of research on L2 Chinese acquisition. Second Language Research.27(4),559-573 